\title{
Innovation of Social Aid Grant Service "Sabilulungan" in Bandung, Indonesia
}

\author{
Dr. Hardi Warsono, M.TP ${ }^{1}$, Sri Indarti, S.Sos, M.Si ${ }^{2}$, Ransta L. LekatompessyS.IP, M.Sc ${ }^{3}$ \\ Public Administration Doctoral Program, Faculty of Social and Political Sciences \\ Diponegoro University \\ Semarang City, Indonesia \\ (Srindarti@gmail.com)
}

\begin{abstract}
Innovation of public service is a necessity in this contemporary era, due to the complexity of public interest and current development requires creativity and innovation in services. This study aimed to examine the profiles, implementation services and challenges in innovation of social aid service "Sabilulungan" grant in Bandung. This descriptive qualitative study was conducted in a way of searching data in the form of observation, documentation and interview. The results shows that the social aid service of Sabilulungan grant is a kind of radical innovation and its implementation has provided benefits and transparency of services. There are several challenges in the implementation of the social aid service of Sabilulungan grant and this research recommends the need of accuracy in terms of completeness grantee, the data base addition in terms of the receiver's certification of registration, the determination of responsible person of the Sabilulungan social aid grant, the development and refinement of Sabilulungan application.
\end{abstract}

\section{Keywords-Innovation Services; Grant; Social aid}

\section{INTRODUCTION}

Public administration is the academic study of the public sector, the orientation of public administration is to meet the public interest. Public service is one of the formal objects of public administration. Services developed by the public administrator orientate to the public interest and provides maximum benefit to the public, in accordance with the demands and expectations of society. In this respect, it has emerged a variety of innovations in public services, which are growing in some areas in various forms of service in the last decade, including the provision of social aid services innovation.

Grants are gifts of money/goods or services from the government to the central government or other regional governments, regional companies, communities and civil society organizations, which have specifically allocation, is not mandatory and not binding, and does not continuously aiming to support the implementation local government affairs. Social aid is providing assistance in the form of cash/goods from local governments to individuals, families, groups and/or people that are not continuously and selectively aimed to protect against the risk of social (Regulation No. 32 of 2011).
Nowadays, the case of social aid is frequently incriminating the bureaucracy in various areas. The city government has developed innovations in social service provision by online, called "Sabilulungan".

\section{DISCUSSION}

\section{A. Profile of Social Aid Services Sabilulungan Grant}

Sabilulungan program, also means 'Mutual-Help' is initiated by the Government of Bandung in order to facilitate the transparency in the embodiment of social aid programs and grants through online media. Sabilulungan program aims to ensure the grants derived by Bandung City Government to finance social projects intended by public is visibly accountable. The whole process in Sabilulungan can be seen and watched by the whole society (see the sabilulungan.go.id).

Applications sabilulungan.go.id inaugurated by the Mayor of Bandung on December 23, 2013 and then directly applied in accordance with the commitment of the head region. The data of the grantee and the aid was uploaded via Online Social Aid Grant with as many as 749 in FY 2013 and 205 beneficiaries in FY 2014. E-social aid has been the first innovation enabling the government to deliver social aid or grant without any deviation interest. E- social aid and Sabilulungan grant are innovation in the service of Public Administration and became top 99 Public Service Innovation of Indonesia in 2015 held by the ministry of state apparatus utilization and Bureaucracy Reformation of Republic of Indonesia.

Sabilulungan service innovation got a positive response from the community, from the first establishment to the process of implementation, this can be seen on Ridwan Kamil's facebook in which around 987 people expressed their love/support. There are also criticized by People's Aspirations and Complaints Online Service (www.lapor.go.id) as well as many people curious about more details regarding the management of grants and social aid in Bandung. It can be seen on the site www.academia.edu which is today has been accessed from all over Indonesia in 3147 times. Unfortunately, the access number sabilulungan.bandung.go.id cannot be seen this time. 


\section{B. Implementation of Sabilulungan Innovation Service}

Social Aid Services of Sabilulungan grant has been implemented for two years. Through Sabilulungan, whole communities and organizations in the city of Bandung be able to:

- Submitting proposals related to grant social aid and monitor how the status of the proposal ( whether accepted, rejected, being verified, and so on); and

- Participate in monitoring social aid grants approved by the Government of Bandung so that it provides input and advice regarding the course of the social aid grant.

Each community or organization in the city who want to apply for a social aid grant proposal through Sabilulungan simply register through the application and send documents directly, then it will be verified by the Government of Bandung. Each stage starts from the application, the Related SKPD Evaluation, Assessment Team Considerations and TAPD visualize through online social aid of Sabilulungan grant. Then the process of submission of the SPP, SPM and SP2D is using other applications and keep visualized so that the community still can be determine whether the activity is already running. Realization of grant recipients is as follows:

TABLE I. REALIZATION GRANTEES AND SOCIAL AID FOR COMMUNITY ORGANIZATIONS, NGO, BANDUNG COMMUNITY GROUPS YEAR 2012-2014

\begin{tabular}{|c|c|c|c|c|}
\hline \multirow{2}{*}{ Year } & \multicolumn{2}{|c|}{ Number of Beneficiary } & \multicolumn{2}{c|}{ Beneficiaries' realisation } \\
\cline { 2 - 5 } & Grants & Social Aids & Grants & Social Aids \\
\hline 2012 & 4058 & 14 & 2016 & 11 \\
\hline 2013 & 1244 & 156 & 593 & 155 \\
\hline 2014 & 439 & 285 & 156 & 154 \\
\hline
\end{tabular}

Source: Department of Finance and Asset Management of Bandung

Implementation and evaluation of this program involves the participation of the community, which is done through sabilulungan.bandung.go.id, where it is indirectly contribute to solving the problem of grants and social aid in Bandung. The public can also help provide comments and suggestions via the mass media, People's Aspirations and Complaints Online Services, discussions Column of sabilulungan.bandung.go.id and there is a direct report to the authorities in case of deviations activities on the ground.

\section{Challenges}

A major challenge in the implementation of Sabilulungan services, namely: (1) A lot of interests need to be accommodated, due to lot of pressure from both the interests of community welfare and political interests. (2) Regulation grants and social aid sourced from the budget quite complete, but actually supporting regulations as an explanation is still necessary. (3) The lack of coordination between SKPD and SKPD had to go to the field checking out the real situation, since there are findings that electrical poles functioned as an address. (4) There are many social aid grantees are not based by name, by address. (5) Need to increase the commitment to manage sabilulungan.bandung.go.id. (6) Application is not complete, additional needs such as E-ID Data Base and Legal
Organization. The Web templates is also not satisfactory, there are column filled with incorrect information or has been made but unfilled, and updating information with a focus on the urgent information such as a list of grant beneficiaries along with the amount of funds received.

\section{RECOMMENDATIONS}

Recommendation as a positive proposal in order to smooth implementation Sabilulungan services and service development for a better life, are:

- SKPD needs to be hold careful review of the completeness of the requirements of the recipient and address clearly in the Proposal and Accountability Grants and Social aid Report.

- Reporting the running program in accordance with the procedure, but to note the timeliness of the reporting institution or foundation along with the accessories, to minimize the misunderstanding or suspicion of the Institute or the Foundation.

- Addition of Data Base Registration Certificate (SKT) for organizations and institutions so that the coordination with related SKPD SKT administration is more easily and accurately.

- Establishment of Coordinator/Responsible Online Social Aid Sabilulungan Grants.

- Updating information in Sabilulungan web template, so that the information in the text can be for the user, such as the certainty of grant recipients and the amount of funds disbursed.

- Need some Changes on Mayor's Regulation of Grants and Social aid for the development and improvement of Sabilulungan application, which includes planning coordination system and the flow of work, as well as the allocation of human and financial resources.

\section{CONCLUSION}

Social Aid and grants Services "Sabilulungan" is an innovation in the public service, which the program is oriented towards the public interest and can encourage the participation of the community to achieve prosperity and progression. The program includes radical innovation, since it is directly applied in line with the commitment of the regional head of the program. The implementation process of the services that had been done is a maturation process that shows that there are opportunities, constraints, challenges and loopholes alternative solutions for the development of innovation in the next period. Internalization of the service implementation process should be able to generate ideas modifications and continue the innovation in the implementation of policies so that the next implementation will be more successful and can accelerate the achievement of the policy objectives, and can be used as a comparison to innovate services in many other regions in Indonesia. 


\section{REFERENCES}

[1] Sabilulungan.bandung.go.id

[2] Jones, G.R. 2004, Organizational Theory, Design and Change, PrenticeHall

[3] Indarti, Sri, 2015, Implementasi dan Inovasi Kebijakan PDB Samisake di Kota Bengkulu dalam Rangka Menyongsong Masyarakat Ekonomi $A S E A N$, dalam proseding Seminar Nasional DAP UNDIP, Semarang
[4] Ridwan Kamil, Facebook

[5] www.lapor.go.id

[6] Kelembagaan Pemenuhan Hak atas Informasi

[7] Oleh: Pius Widiyatmoko, peneliti Perkumpulan INISIATIF

[8] http://www.academia.edu/8082913/Kelembagaan_Pemenuhan_Hak_atas Informasi 